\title{
ANALISIS PENGARUH DANA ALOKASI UMUM (DAU) DAN PENDAPATAN ASLI DAERAH (PAD) TERHADAP PERTUMBUHAN BELANJA DAERAH DI KOTA BITUNG
}

\author{
Elce Yuliana Sumangkut ${ }^{1}$, Paulus Kindangen ${ }^{2}$, Een N. Walewangko ${ }^{3}$ \\ Fakultas Ekonomi dan Bisnis, Magister Ilmu Ekonomi \\ Universitas Sam Ratulangi, Manado
}

\begin{abstract}
ABSTRAK
Pengelolaan keuangan daerah berkaitan erat dengan penyelenggaraan urusan pemerintahan melalui pelaksanaan desentralisasi, fungsi pemerintahaan tertentu dilimpahkan kepada pemerintah daerah dengan tujuan untuk meningkatkan nilai tambah dalam penyelenggaraan pemerintahan.

Pada umumnya Anggaran Pendapatan dan Belanja Daerah (APBD) suatu daerah didominasi oleh sumbangan pemerintah dan sumbangan-sumbangan lain, yang diatur dengan peraturan perundang-undangan. Hal ini menyebabkan daerah sangat tergantung kepada pemerintah pusat.

Nilai koefisien sebesar 0.07 akan tetapi tidak signifikan. Hal ini menunjukkan bahwa perkembangan belanja daerah Kota Bitung memiliki hubungan yang positif dengan berubahnya PAD. Dengan perkataan lain, selama periode yang diteliti, dengan menjaga agar variabel-variabel lain tetap, 1 persen peningkatan dalam PAD akan mengakibatkan peningkatan rata-rata sekitar 0.07 persen dalam belanja daerah.

Nilai koefisien sebesar 1,07 dan signifikan menunjukkan bahwa perkembangan belanja daerah memiliki hubungan yang positif dengan perubahan dana alokasi umum. Dengan perkataan lain, selama periode penelitian, dengan menjaga agar variabel-variabel lain tetap, 1 persen peningkatan DAU akan mengakibatkan peningkatan rata-rata sekitar 1,07 persen dalam belanja daerah Kota Bitung.

Hasil regresi sederhana dan regresi berganda menunjukkan bahwa peningkatan pendapatan asli daerah (PAD) dan dana alokasi umum (DAU) berpengaruh positif terhadap peningkatan belanja daerah (BD) dan dalam pengelolaan keuangan daerah Kota Bitung Tahun Anggaran 2004-2015 membuktikan terjadinya Flypaper Effect.
\end{abstract}

Kata Kunci: Dana Alokasi Umum, Pendapatan asli Daerah, Belanja Daerah

\section{ABSTRACT}

Financial management is closely related to the implementation of government affairs through decentralization, certain governance functions delegated to local governments with the aim to increase the value added in governance.

In general, the Regional Budget (APBD) an area dominated by government contributions and other donations, which is regulated by legislation. This causes the region is highly dependent on the central government.

The coefficient value of 0:07 will but not significantly. This suggests that the development of shopping areas Bitung City have a positive correlation with the change in revenue. In other words, during the period under study, by keeping other variables remain, a 1 percent increase in revenue would result in an average increase of 0.07 percent in the shopping area.

Values of 1.07 and significant coefficient indicates that the development of shopping areas have a positive correlation with the change in the allocation of public funds. In other words, during the study period, by keeping other variables remain, a 1 percent increase in DAU will result in an average increase of about 1.07 percent in the shopping area of the city of Bitung.

The results of simple regression and multiple regression showed that the increase in local revenue (PAD) and the general allocation fund (DAU) positive effect on the increase in shopping areas $(B D)$ and the financial management of Bitung City Fiscal Year 2004-2015 to prove the occurrence of flypaper.

Keywords: General Allocation Fund, Local Revenue, Local Expenditure

\section{PENDAHULUAN}

\section{Latar Belakang}

Sejak 1 Januari 2001, Indonesia memulai babak baru penyelenggaraan pemerintahan, dimana otonomi daerah diberikan kepada seluruh wilayah di Indonesia, baik provinsi maupun kabupaten/kota. Dalam pelaksanaan otonomi daerah yang merupakan perwujudan desentralisasi, banyak daerah belum mampu secara mandiri melaksanakan segala aktivitasnya sehingga masih tergantung aspek pembiayaannya 
terhadap pemerintah pusat. Menurut UU No. 23 tahun 2014 tentang pemerintahan daerah untuk pelaksanaan kewenangan pemerintah daerah, pemerintah pusat akan mentransfer dana perimbangan pada pemerintah daerah. Dana perimbangan tersebut terdiri dari Dana Alokasi Umum (DAU), Dana Alokasi Khusus (DAK) dan Bagi Hasil Pajak Pusat (BHPP). Pemerintah daerah memiliki sumber pendanaan sendiri berupa Pendapatan Asli Daerah (PAD), Pinjaman Daerah, dan Lain-Lain Penerimaan Daerah Yang Sah. Kebijakan penggunaan semua dana diserahkan kepada pemerintah daerah (Prakoso, 2004 hal 24).

Pengelolaan keuangan daerah berkaitan erat dengan penyelenggaraan urusan pemerintahan melalui pelaksanaan desentralisasi, fungsi pemerintahaan tertentu dilimpahkan kepada pemerintah daerah dengan tujuan untuk meningkatkan nilai tambah dalam penyelenggaraan pemerintahan. Pemberlakuan UndangUndang nomor 23 tahun 2014 tentang pemerintah daerah dengan esensi kebijakan otonomi daerah yang bergulir dewasa ini merupakan wujud dari kewenangan dalam bidang keuangan daerah. Kebijakan otonomi daerah itu dimaksudkan untuk semakin mendekatkan pemerintah kepada masyarakat agar pelayanan yang diberikan menjadi semakin baik. Menurut Suparmoko (2002 hal 32), dengan semakin mendekatkannya pemerintah kepada masyarakat diharapkan pelayanan publik dapat dapat diwujudkan lebih baik sesuai dengan kebutuhan masyarakat.

Otonomi daerah bukan lagi hanya suatu retorika belaka namun telah menjadi realita dan karena itu harus dengan semangat untuk semakin memajukan daerah dalam Negara Kesatuan Republik Indonesia. Kebijakan otonomi daerah harus senantiasa disikapi dengan kerja keras agar harapan pemerintah dan masyarakat daerah dapat terwujud. Efisiensi dan efektivitas penyelengaraan pemerintahan daerah perlu ditingkatkan dengan lebih memperhatikan aspek-aspek hubungan antar pemerintahan daerah, memperhatikan potensi dan keanekaragaman daerah dan memperhatikan peluang dan tantangan persaingan global. Untuk mencapai tujuan tersebut maka diperlukan kesiapan dana (financial) yang cukup besar, sehingga daerah dituntut mampu menggali berbagai potensi sumber keuangan daerah. Sumber-sumber keuangan daerah, (Suparmoko, 2011, hal 45) terdiri dari, yaitu :
a. PAD
b. Dana perimbangan (Dana Bagi Hasil, DAU, DAK)
c. Pinjaman Daerah
d. Dana Dekonsentrasi
e. Dana Tugas Pembantuan

Tiga sumber dana yang pertama langsung dikelola oleh pemerintah daerah melalui Anggaran Pendapatan Belanja Daerah, sedangkan sumber dana lainnya dikelola oleh pemerintah pusat melalui kerja sama dengan pemerintah daerah. Jadi sumber pendanaan bagi pelaksanaan pemerintahan daerah terdiri atas PAD, dana perimbangan, dan lain-lain pendapatan yang sah. Kebijakan penggunaan dana diserahkan kepada pemerintah daerah (Prakosa, 2004 hal 27). Dalam pelaksanaan desentralisasi, peran dana transfer tidak dapat dihindarkan mengingat otonomi yang dilimpahkan menuntut daerah untuk dapat menyelesaikan berbagai urusan pemerintahan yang menjadi wewenang daerah dalam hal pembiayaan.

Keadaan tersebut juga di temui di kota Bitung, transfer pemerintah pusat khususnya yang di dominasi oleh transfer tidak bersyarat yaitu DAU dan DBH masih tampak berpengaruh dalam pembiayaan pembangunan. $\mathrm{Hal}$ ini terlihat dari besarnya porsi penerimaan transfer tidak bersyarat yang diperoleh daerah Kota Bitung pada Tahun 2014 dari pada sumber penerimaan lainnya seperti transfer bersyarat, PAD atau pendapatan lainlain. Gambar 1.1 menunjukkan bahwa pendapatan daerah Kota Bitung pada tahun 2014 peranan PAD hanya sebesar 13\%, DAK sebesar 8\%, dan DAU 79\%. Hal tersebut menunjukkan dalam perolehan pendapatan daerah Kota Bitung sangat didominasi oleh Dana Transfer Pusat dengan total besarannya mencapai 87\%, sedang Peranan PAD masih rendah hanya sebesar $13 \%$.

Perkembangan perekonomian kota Bitung juga dipengaruhi oleh pengeluaran pemerintah daerah. Adapun untuk perkembangan perekonomian daerah kota Bitung dapat dilihat melalui pertumbuhan ekonomi yang ditunjukkan pada gambar 1.2. Pertumbuhan Ekonomi Kota Bitung pada tahun 2006 mengalami pertumbuhan terendah hanya sebesar 2,3\%, pada tahun 2012 merupakan pertumbuhan tertinggi dengan capaian $8,0 \%$ dan rata-rata pertumbuhannya sebesar $6,5 \%$. Secara keseluruhan walaupun pertumbuhan ekonomi mengalami fluktuasi akan tetapi mempunyai trend yang positif. 
Dana desentralisasi fiskal pemerintah pusat termuat dalam undang-undang otonomi daerah dipergunakan untuk membangun sarana dan prasarana publik dan pemerintahan. Pembangunan ini selanjutnya akan mendorong pertumbuhan ekonomi. Melihat kenyataan bahwa transfer tidak bersyarat menjadi sumber dana utama dalam menunjang pembiayaan pembangunan yang ada di Kota Bitung, transfer tidak bersyarat diperkirakan sebagai faktor penting yang mendorong tingkat pertumbuhan ekonomi. Melihat kenyataan bahwa transfer tidak bersyarat menjadi sumber dana utama dalam menunjang pembiayaan pembangunan di kota Bitung, hal ini mengindikasikan adanya dampak fenomena flypaper effect dimana porsi belanja pemerintah daerah bersumber dari transfer tidak bersyarat (dana alokasi umum/DAU).

Adapun perkembangan belanja pemerintah daerah dan transfer tidak tidak bersyarat dapat dilihat pada gambar 1.3. Gambar 1.3 menunjukkan bahwa trend dari belanja daerah lebih curam dari pada trend dana transfer tidak bersyarat, dimana artinya bahwa peningkatan belanja daerah lebih besar dari peningkatan transfer tidak bersyarat (DAU). Hal tersebut mengindikasikan terjadinya gejala flypaper effect yang memperlihatkan adanya peningkatan alokasi transfer dengan diikuti oleh peningkatan belanja yang lebih tinggi, Purnomo (2011). Selanjutnya menurut Maimunah (2006) bahwa flypaper effect disebut sebagai suatu kondisi yang terjadi saat pemerintah daerah merespon (belanja) lebih banyak (lebih boros) dengan menggunakan dana transfer (grants) yang diproksikan dengan DAU dari pada menggunakan kemampuan sendiri, diproksikan dengan PAD.

\section{Rumusan Masalah}

Berdasarkan latar belakang, maka dua masalah penelitian yang dapat dirumuskan :

1. Bagaimana pengaruh Dana Alokasi Umum (DAU) dan Pendapatan Asli Daerah (PAD) terhadap pertumbuhan belanja daerah Kota Bitung?

2. Apakah terjadi flypaper effect pada pengaruh DAU dan PAD terhadap belanja daerah Kota Bitung?

\section{Tujuan Penelitian}

Berdasarkan rumusan masalah di atas maka tujuan penulisan ini adalah untuk memberikan bukti empiris pada :

1. Untuk mengetahui bagaimana pengaruh DAU dan PAD terhadap belanja daerah Kota Bitung?

2. Untuk mengetahui kemungkinan terjadinya Flypaper Effect pada belanja daerah Kota Bitung?

\section{Manfaat Penelitian}

Beberapa manfaat yang diharapkan dalam penelitian ini adalah berupa kontribusi empiris, teori dan kebijakan, yaitu :

1. Kontribusi empiris, untuk memperkuat penelitian sebelumnya, berkenaan dengan kemungkinan adanya flypaper effect yang terjadi dalam transfer dana (DAU) dan PAD terhadap Belanja daerah yang dilakukan secara empiris pada Kota Bitung.

2. Kontribusi kebijakan, memberikan masukan baik bagi Pemerintah Pusat maupun Daerah dalam hal penyusunan kebijakan di masa yang akan datang yang berkaitan dengan perencanaan, pengendalian, dan evaluasi dari APBN dan APBD, serta UU dan PP yang menyertainya.

3. Kontribusi teori, sebagai bahan referensi dan data tambahan bagi peneliti-peneliti lainnya yang tertarik pada bidang kajian ini.

\section{LANDASAN TEORI}

Teori Transfer

Dalam UU No.32/2004 disebutkan bahwa untuk pelaksanaan kewenangan Pemda, Pempus akan mentransfer Dana Perimbangan yang terdiri dari Dana Alokasi Umum (DAU), Dana Alokasi Khusus (DAK), dan bagian daerah dari Dana Bagi Hasil yang terdiri dari pajak dan sumber daya alam. Transfer merupakan konsekuensi dari tidak meratanya kemampuan keuangan dan ekonomi daerah. Selain itu, tujuan transfer adalah mengurangi kesenjangan keuangan horizontal antar daerah, mengurangi kesenjangan vertikal PusatDaerah, mengatasi persoalan efek pelayanan publik antar daerah, dan untuk menciptakan stabilisasi aktifitas perekonomian di daerah. 
Menurut Prakosa (2004), Transfer atau grants dari Pempus secara garis besar dapat dibagi menjadi dua, yakni matching grant dan non-matching grant. Kedua grants tersebut digunakan oleh Pemda untuk memenuhi belanja rutin dan belanja pembangunan. Belanja rutin adalah belanja yang sifatnya terus menerus untuk setiap tahun fiskal dan umumnya tidak menghasilkan wujud fisik (contoh: belanja gaji dan honorarium pegawai), sementara belanja pembangunan umumnya menghasilkan wujud fisik, seperti jalan, jalan bebas hambatan (highway), jembatan, gedung, pengadaan jaringan listrik dan air minum, dan sebagainya. Belanja pembangunan non-fisik diantaranya mencakup pendidikan, pelayanan kesehatan, dan pemeliharaan keamanan masyarakat.

Rosen (2002), membagi jenis grant menjadi 2 macam yaitu conditional grant atau categorical grant dan unconditional grant. Conditional grant adalah transfer khusus yang diberikan kepada pemerintahan daerah untuk tujuan khusus, misalnya untuk biaya operasional sekolah (BOS) dan jaring pengaman sosial (JPS). Jadi conditional grant serupa dengan matching grant.unconditional grant diberikan kepada pemerintah daerah tanpa persyaratan tertentu dan pada umumnya berkaitan dengan usaha-usaha produktif untuk investasi pada badan usaha. Sering juga uncondional grant disebut revenue sharing. Menurut Azwardi (2007), transfer tidak bersyarat (Unconditional Grants) di Indonesia adalah dalam bentuk dana alokasi umum (DAU) dan dana bagi hasil (DBH), sedangkan transfer bersyarat (conditional grants) berupa dana alokasi khusus (DAK), (Purnomo, 2011).

\section{Dana alokasi umum (DAU)}

Menurut UU No. 33 Tahun 2004 tentang perimbangan keuangan antara pemerintah pusat dan daerah bahwa yang dimaksud dengan perimbangan keuangan antara pemerintah pusat dan daerah adalah suatu system pembiayaan pemerintah dalam rangka negara kesatuan yang mencakup pembagian keuangan antara pemerintah pusat dan pemerintah daerah serta pemerataan antar daerah secara proposional, demokratis, adil dan transparan dengan memperhatikan potensi, kondisi dan kebutuhan daerah sejalan dengan kewajiaban dan pembagian kewenangan serta tata cara penyelengaraan kewengan tersebut, termasuk pengelolaan dan pengawasan keunagannya. Dana perimbangan yang diperoleh pemerintah daerah terdiri dari dana alokasi umum, dana alokasi khusus, dan dana bagi hasil.

DAU merupakan jenis transfer dana antar tingkat pemerintahan yang tidak terikat dengan program pengeluaran tertentu. DAU ini dimaksudkan untuk mengantikan transfer berupa subsidi daerah otonom dan inpres. Adapun tujuan dari transfer ini adalah untuk menutup kesenjangan fiskal (fiscal gap) dan pemerataan kemampuan fiskal antara daerah dan pusat dan antar daerah. Sehingga dana alokasi umum tiap daerah tidak akan sama besarnya. Daerah yang mempunyai pendapatan asli daerah rendah akan mendapatkan dana alokasi umum yang tinggi, dan begitu juga sebaliknya daerah yang mempunyai pendapatan asli daerah tinggi akan mendapatakan dana alokasi umum yang rendah.

Menurut UU No. 33 Tahun 2004 tentang perimbangan keuangan antara pemerintah pusat dan daerah, jumlah keseluruhan DAU ditetapkan sekurang-kurangnya $26 \%$ dari pendapatan dalam negeri netto yang ditetapkan dalam Anggaran dan Pendapatan Belanja Negara (APBN). DAU suatu daerah dialokasikan atas dasar celah fiskal dan alokasi dasar. Celah fiskal dihitung berdasarkan kebutuhan fiskal daerah dikurangi dengan kapasitas fiskal daerah, sementara alokasi dasar dihitung berdasarkan jumlah Pegawai Negeri Sipil Daerah. Proporsi DAU antara daerah propinsi dan kabupaten/kota ditetapkan berdasarkan perimbangan kewenangan antara propinsi dan kabupaten/kota. Penyaluran dana alokasi umum dilaksanakan tiap bulan masing-masing sebesar $1 / 2$ dari dana alokasi umum daerah yang bersangkutan.

\section{Pendapatan Asli Daerah (PAD)}

Prinsip yang mendasari pendapatan asli daerah adalah melalui desentralisasi fiskal dimana didalamnya terdapat fungsi dan kewenangan daerah yang harus dijalankan. Pemerintah daerah (Pemda) pada prinsipnya harus memiliki kewenangan dan fleksibilitas dalam menentukan prioritas-prioritasnya, serta didukung oleh penerimaan daerah yang memadai. Sumber-sumber penerimaan daerah tidak hanya berasal dari daerah itu sendiri berupa PAD, tetapi juga termasuk bagi hasil (revenue shaing) dan transfer yang berasal dari pusat.

Sesuai dengan asas desentralisasi, pemerintah daerah dapat mengurus rumah tangganya sendiri dengan sebaik-baiknya, maka kepadanya perlu diberikan sumber-sumber pembiayaan yang cukup, tetapi 
akibat dari kebutuhan anggaran Negara sendiri dalam melaksanakan tugas nasional dan asas dekonsentrasi serta tugas pembantuan, maka sumber pembiayaan yang dapat diserahkan kepada daerah adalah terbatas. Karena setiap daerah diwajibkan menggali segala kemungkinan sumber-sumber keuangan sendiri dengan dan dalam batas-batas perundang-undangan yang berlaku. Sumber pendapatan daerah sendiri yang diatur

\section{Belanja Daerah (BD)}

Pendapatan yang diperoleh baik dari pendapatan asli daerah maupun dana perimbangan tentunya digunakan oleh pemerintah daerah untuk membiayai belanja daerah. Menurut UU No. 23 Tahun 2004 tentang pemerintah daerah, belanja daerah adalah semua kewajiban daerah yang diakui sebagai pengurang nilai kekayaan bersih dalam periode tahun anggaran yang bersangkutan. Berdasarkan struktur anggaran daerah, elemen-elemen yang termasuk dalam beanja daerah terdiri dari:

1. Belanja aparatur daerah

Bagian belanja yang berupa : belanja administrasi umum, belanja operasi dan pemeliharaan, serta belanja modal atau pembangunan yang dialokasikan atau digunakan untuk membiayai kegiatan yang hasil, manfaat, dan dampaknya tidak secara langsung dinikmati oleh masyarakat (publik)

2. Belanja pelayanan publik

Bagian belanja yang berupa : belanja administrasi umum, belanja operasi dan pemeliharaan, serta belanja modal atau pembangunan yang dialokasikan atau digunakan untuk membiayai kegiatan yang hasil, manfaat, dan dampaknya secara langsung dinikmati oleh masyarakat.

3. Belanja bagi hasil dan bantuan keuangan

Pengeluaran uang dengan criteria :

a. Tidak menerima secara langsung imbalan barang dan jasa seperti layak terjadi dalam transaksi pembelian dan penjualan

b. Tidak mengharap dibayar kembali pada masa yang akan datang seperti yang diharapkan pada suatu pinjaman.

c. Tidak mengharapkan adanya hasil pendapatan seperti layak yang diharapkan pada kegiatan investasi.

4. Belanja tidak tersangka

Pengeluaran yang disediakan untuk :

a. Kejadian-kejadian luar biasa seperti bencana alam, kejadian yang dapat membahayakan daerah

b. Utang (pinjaman) periode sebelumnya yang belum diselesaikan dan atau yang tersedia anggarannya pada tahun yang bersangkutan.

c. Pengembalian penerimaan yang bukan haknya atau penerimaan yang dibebaskan (dibatalkan) dan atau kelebihan penerimaan.

Namun pada prakteknya belanja pemerintah daerah dibagi dalam dua bentuk seperti yang terdapat dalam laporan realisasi anggaran dan pendapatan belanja daerah yakni sebagai berikut:

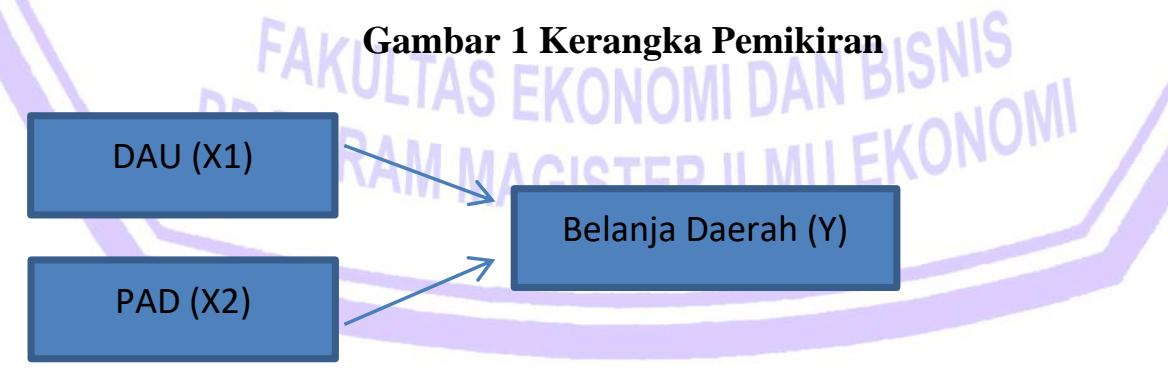

\section{METODE PENELITIAN}

\section{Data Dan Sumber Data}

Data yang digunakan dalam penelitian ini merupakan data sekunder dengan jenis data time series. Data tersebut berupa Laporan Realisasi Anggaran Pendapatan Dan Belanja Daerah Pemerintah Kota Bitung 
Tahun 2004-2015 yang berupa realisasi belanja daerah (BD), realisasi dana DAU, realisasi PAD, yang bersumber dari:

1. Badan Pusat Statistik (BPS) Kota Bitung

2. Badan Pengelola Keuangan dan Barang Milik Daerah Kota Bitung

3. Badan Perencanaan dan Pembangunan Daerah (BAPPEDA) Kota Bitung

\section{Metode Pengolahan Data}

Penelitian ini dilakukan dengan menggunakan analisis deskriptif dan kuantitatif. Analisis deskriptif didasarkan pada studi literarur melalui artikel, buku-buku dan hasil penelitian yang berhubungan dengan anggaran pendapatan dan belanja daerah (APBD) Kota Bitung. Sedangkan dalam analisis kuantitatifnya digunakan model ekonometrika untuk mencerminkan hasil dan pembahasan yang dinyatakan dalam angka.

\section{Ruang Lingkup Penelitian}

Penelitian ini membatasi dan memfokuskan pada pengelolaan keuangan daerah dengan menganalisis hubungan PAD dan DAU terhadap belanja daerah (BD) di era otonomi daerah pada Kota Bitung dengan data yang digunakan merupakan data tahunan tahun 2004 sampai tahun 2015.

\section{Definisi dan Pengukuran Variabel}

Definisi operasional variabel adalah suatu definisi yang diberikan pada suatu variabel atau dengan cara memberikan arti atau menspesifikasikan kegiatan ataupun membernarkan suatu operasional yang diperlukan untuk mengukur variable tersebut. Variable terikat (dependent variable) dalam penelitian ini adalah belanja daerah variable bebas (Independent Variabel) adalah DAU dan PAD. Adapun definisi operasional sebagai berikut:

\section{Belanja Daerah}

Belanja daerah adalah semua pengeluaran pemerintah daerah pada suatu periode anggaran. Belanja daerah dalam penelitian ini dapat diketahui dari pos belanja daerah dalam laporan realisasi anggaran pemerintah Kota Bitung tahun anggaran 2004-2015, dalam satuan rupiah.

- Pendapatan Asli Daerah

PAD yang terdiri dari hasil pajak daerah, retribusi daerah, pendapatan dari laba perusahaan daerah dan lainlain pendapatan yang sah. Pendapatan asli daerah dalam penelitian ini diperoleh dari laporan realisasi anggaran pemerintah Kota Bitung tahun anggaran 2004-2015, dalam satuan rupiah.

- Dana Alokasi Umum

DAU adalah transfer yang bersifat umum dari pemerintah pusat ke pemerintah daerah untuk mengantisipasi ketimpangan horizontal dengan tujuan utama pemerataan kemampuan keuangan antar daerah. DAU diperoleh dengan melihat dari dana perimbangan yang ada di laporan realisasi anggaran pemerintah Kota Bitung tahun anggaran 2004-2015, dalam satuan rupiah.

\section{- Flypaper Effect}

Flypaper Effect disebut sebagai suatu kondisi yang terjadi saat pemerintah daerah merespon (belanja) lebih banyak (lebih boros) dengan menggunakan dana transfer (grants) yang diproksikan dengan DAU dari pada kemampuan sendiri, diproksikan dengan PAD.

\section{Metode Analisis}

Metode analisis yang digunakan adalah analisis kualitatif dan kuantitatif, yang akan dijelaskan sebagai berikut :

1. Kualitatif dilakukan dengan menggunakan beberapa instrumen analisis seperti tabel dan grafik serta analisis rasio yang dapat mencerminkan uraian analisis penelitian secara teratur dan saling mendukung.

2. Kuantitatif dilakukan dengan menggunakan model ekonometrika dengan bantuan program Eviews dan Microsoft Excel. 


\section{Model Ekonometrika}

Alat analisis yang digunakan dalam penelitian ini adalah regresi sederhana (simple regression) dan regresi berganda (multiple regression). Teknik yang digunakan untuk mencari nilai persamaan regresi yaitu dengan analisis Ordinary Least Squares (OLS) dengan meminimalkan jumlah dari kuadrat kesalahan.

Analisis regresi sederhana digunakan untuk melihat pengaruh masing-masing jumlah DAU dan PAD terhadap jumlah Belanja Daerah (BD) dengan persamaan sebagai berikut :

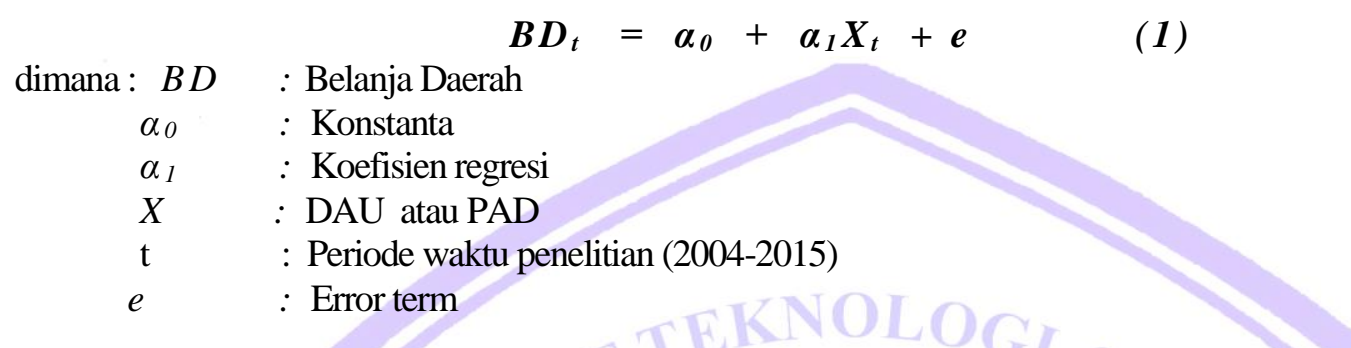

Analisis regresi berganda digunakan untuk memprediksi apakah DAU dan PAD tersebut secara serempak mempengaruhi Belanja Daerah. Persamaan regresi yang digunakan adalah sebagai berikut:

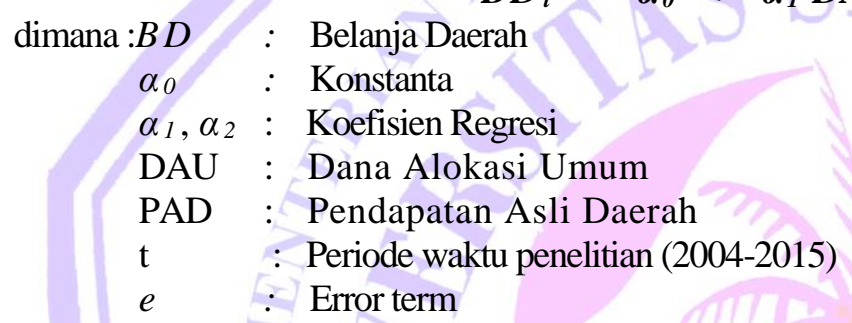

$$
B D_{t}=\alpha_{0}+\alpha_{1} D A U_{t}+\alpha_{2} P A D_{t}+e_{t}(2)
$$

Persamaan (1) dan persamaan (2) ditransformasikan ke dalam bentuk log-natural. Hal ini dilakukan untuk melihat pengaruh pertumbuhan PAD dan DAU terhadap pertumbuhan Belanja Daerah (BD). Persamaan regresi yang telah di log-natural ditunjukkan oleh persamaan (3) dan persamaan (4).

dimana $L B D$ : Pertumbuhan Belanja Daerah

$$
L B D_{t}=\alpha_{0}+\alpha_{1} L X_{t}+e
$$

$\alpha_{0} \quad$ : Konstanta

$\alpha_{1} \quad$ : Koefisien Regresi

LX : Pertumbuhan DAU dan PAD

t : : Periode waktu penelitian (2004-2015)

e : Error term

dimana $: L B D$ : Pertumbuhan Belanja Daerah

$$
L B D_{t}=\alpha_{0}+\alpha_{1} L D A U_{t}+\alpha_{2} L P A D_{t}+e_{t} \text { (4) }
$$

$\alpha_{0} \quad:$ Konstanta

$\alpha_{1}, \alpha_{2}:$ Koefisien Regresi

LDAU : Pertumbuhan Dana Alokasi Umum

LPAD : Pertumbuhan Pendapatan Asli Daerah

t : Periode waktu penelitian (2004-2015)

$e \quad:$ Error term

\section{Uji Model}

Pengujian regresi linier berganda dapat dilakukan setelah model dari penelitian ini memenuhi syaratsyarat yaitu lolos dari asumsi klasik. Syarat-syarat yang harus dipenuhi adalah data tersebut harus terdistribusikan secara normal, tidak mengandung multikoloniaritas, dan heterokedastisitas. Untuk itu sebelum melakukan pengujian regresi linier berganda perlu dilakukan lebih dahulu pengujian asumsi klasik, yang terdiri dari: 


\section{Uji Normalitas}

Pengujian normalitas memiliki tujuan untuk menguji apakah dalam model regresi, variabel penganggu atau residual memiliki distribusi normal. Seperti diketahui bahwa uji t mengasumsikan bahwa nilai residual mengikuti distribusi normal. Kalau asumsi ini dilanggar maka uji statistik menjadi tidak valid untuk jumlah sampel kecil. Untuk menguji normalitas data, penelitian ini menggunakan Jarque-Berra Test. Dari hasil Jarque-Berra Test, jika probality value lebih besar dari $\alpha=0.05$ (5\%) maka data berdistribusi normal, (Pratomo, 2007).

\section{Uji Multikolinearitas}

Multikolineariti dapat diartikan sebagai hubungan linear diantara beberapa atau semua variabel independen dalam sebuah model regresi. Uji ini diperlukan agar CLRM ( Classical Linear Regression Model ) terpenuhi, yaitu suatu kondisi dimana terdapat hubungan yang linear sempurna di antara beberapa atau semua variabel independen dalam sebuah model regresi. Multikolineariti dapat dideteksi apabila nilai $\mathrm{R}^{2}$ yang tinggi dan uji-F yang signifikan, tetapi banyak koefisien regresi dalam uji-t yang tidak signifikan, Nachrowi (2006). Pendeteksian adanya multikolineariti dapat juga dengan cara menghitung koefisien korelasi antar variabel independen, Winarno (2007). Dalam penelitian ini, uji multikolinearitas dilakukan dengan menggunakan kaidah "Corelation Matrix". Penggunaan kaidah ini dilakukan dengan cara melihat keofisien antara variabel bebas. Jika koesien korelasi diantara masing-masing variabel bebas lebih besar 0,8 , maka terjadi Multikolinearitas, (Pratomo, 2007).

\section{Uji Heteroskedastisitas}

Salah satu asumsi yang harus dipenuhi agar taksiran parameter dalam model regresi bersi fat BLUE maka semua residual error mempunyai varian yang sama. Kondisi seperti itu disebut dengan homokedastis. Sedangkan bila varian tidak konstan atau berubah-ubah disebut heterokedastis. Untuk mendeteksi adanya masalah heterokedastisitas akan digunakan uji-formal, yaitu uji-White yang telah tersedia dalam program siap pakai Eviews. Dari hasil uji-White, jika nilai probality value lebih rendah dari $\alpha=0.05(5 \%)$ berarti terdapat Heterokedastisitas, (Pratomo, 2007).

\section{Uji Autokorelasi}

Autokorelasi adalah korelasi antar anggota serangkaian observasi yang diurutkan menurut waktu (seperti dalam data deretan waktu) atau ruang (seperti dalam data cross sectional). Pada penelitian in menggunakan Langrange Multiplier (LM Test) untuk mengetahui adanya autokorelasi dalam model regresi. Jika hasil estimasi nilai probality value lebih rendah dari $\alpha=0.05(5 \%)$ menunjukkan bahwa hasil estimasi tersebut adalah signifikan, bahwa terdapat autokorelasi, (Pratomo, 2007).

\section{Pengujian Statistik}

Dalam melakukan penelitian, untuk keabsahan suatu model perlu dilakukan pengujian-pengujian statistik. Menurut Gujarati (2003), hal ini perlu dilakukan agar suatu model tidak diragukan lagi.

\section{Uji F-statistik}

Uji F digunakan untuk mengetahui apakah variabel-variabel independen dalam persamaan regresi tersebut mempengaruhi variabel dependen secara bersamaan dengan tingkat signifikansi tertentu, (Suharyadi, 2009). Formula yang digunakan untuk Uji F-statistik ditunjukan oleh persamaan (5).

$$
\mathrm{F}=\frac{\mathrm{R}^{2} /(\mathrm{k}-1)}{\left(1-\mathrm{R}^{2}\right) /(\mathrm{n}-\mathrm{k})}
$$

Keterangan :

$\mathrm{F} \quad=$ signifikan hubungan kedua variabel

$\mathrm{R}^{2} \quad=$ koefisien determinasi

$\mathrm{n} \quad=$ banyaknya pengamatan

$\mathrm{k} \quad=$ jumlah variabel yang diamati 


\section{Uji t-statistik}

Untuk mengetahui apakah variabel independen mempunyai pengaruh terhadap variabel dependen secara parsial, maka dilakukan uji t.

Formula yang digunakan untuk Uji t-statistik ditunjukan oleh persamaan (6).

$$
t=\frac{\hat{\beta}_{i}-\beta_{i}}{S E\left(\hat{\beta}_{i}\right)} \quad \text {. . . . . . }
$$

$$
\begin{array}{ll}
\text { Keterangan : } & \hat{\beta}_{\mathrm{i}}=\text { hasil estimasi } \\
& \beta_{\mathrm{i}}=\text { parameter sesuai dengan hipotesis Ho } \\
\operatorname{se}\left(\beta_{\mathrm{i}}\right)=\text { standar error regresi }
\end{array}
$$

\section{Koefisien Determinasi}

Dalam pengukuran ketepatan suatu garis regresi digunakan koefisien determinasi $\left(\mathrm{R}^{2}\right)$. Koefisien determinasi $\left(\mathrm{R}^{2}\right)$ yaitu angka yang menunjukkan besarnya derajat kemampuan menerangkan variabel bebas terhadap variabel tak bebas dari fungsi tersebut. Nilai $R^{2}$ berkisar $0<R^{2}<1$ dimana semakin mendekati 1 maka semakin baik garis regresi karena mampu menjelaskan data aktualnya. Hal tersebut menunjukkan bahwa variabel-variabel bebas yang dimasukkan dalam model regresi mampu dengan baik menjelaskan variasi atau perubahan dari variabel tidak bebas. Semakin mendekati angka nol maka garis regresi menjadi kurang baik karena variabel bebasnya kurang mampu menjelaskan variasi atau perubahan dari variabel tidak bebas, (Widarjono, 2013).

\section{Pengujian Terhadap Flypaper Effect}

Flypaper effect merupakan suatu kondisi keuangan pemerintah daerah yang membelanjakan lebih banyak atau lebih boros dengan menggunakan dana transfer dari pemerintah pusat (DAU) dibandingkan menggunakan dana sendiri (PAD). Untuk menentukan apakah terjadi Flypaper effect perlu dilihat hasil regresinya. Dalam regresi sederhana dan regresi berganda, koefisien regresi, nilai t-statistic, F-Statistic, $\mathrm{R}^{2}$, dan Adjusted $\mathrm{R}^{2}$ masing-masing variabel (regresi) dibandingkan antara DAU dan PAD. Apabila efek yang ditimbulkan oleh perubahan DAU terhadap BD lebih besar daripada efek yang ditimbulkan PAD terhadap BD maka dapat disimpulkan terjadi Flypaper Effect, (Halim dan Abdulah, 2004).

\section{HASIL DAN PEMBAHASAN}

\section{Hasil Regresi Sederhana}

Analisis hasil regresi membahas tentang hubungan antara variabel independen terhadap variabel dependen. Dalam penelitian ini menjadikan pertumbuhan belanja daerah (LBD) sebagai variabel tidak bebas, variabel pertumbuhan dana alokasi umum (LDAU) dan pendapatan asli daerah (PAD) masing-masing sebagai variabel bebas. Estimasi dilakukan dengan metode Ordinary Least Square (OLS). Hasil estimasinya dapat dilihat pada tabel 4.2 dan pada tabel 1 .

\begin{tabular}{|c|c|c|c|}
\hline & LBD & $=-6.996425+$ & 1.278416 LDAU \\
\hline Std. Error & & 1.643276 & 0.0624 \\
\hline t-Statistic & & -2.84965 & 19.09164 \\
\hline$R^{2}=0.97329$ & & & \\
\hline
\end{tabular}

Tabel 1Pengaruh PAD Terhadap BD

\begin{tabular}{|lcc|}
\hline & LBD $=13.74132+0.542653$ LPAD \\
Std. Error & 1.967234 & 0.082416 \\
$t$-Statistic & 6.985096 & 6.584283 \\
$R^{2}=0.812568$ & & \\
Sumber : Output Eviews
\end{tabular}

Tabel 2 Pengaruh DAU Terhadap BD

Sumber : Output Eviews 


\section{Pengujian Statistik}

\section{Uji t-statististik}

Dengan menguji dua arah dalam tingkat signifikansi (Confidence Level atau $C L$ ) dan derajat kebebasan (degree of freedom $)=(\alpha, \mathrm{n}-\mathrm{k})$, dimana $\alpha$ menunjukkan tingkat kepercayaan analisis $(\alpha=5 \%$ atau $\alpha=$ $0,05$,$) , n menunjukkan jumlah observasi (\mathrm{n}=12)$, dan $\mathrm{k}$ menunjukkan jumlah parameter termasuk konstanta $(\mathrm{k}=2)$, hasil pengujian akan menghasilkan salah satu dari dua kesimpulan.

Bila $-\mathrm{t}_{\text {tabel }}<\mathrm{t}_{\text {hitung }}<\mathrm{t}_{\text {tabel }}$ maka Ho tidak ditolak dan menolak Hi

(Berarti variabel bebas secara individual tidak berpengaruh terhadap variabel tak bebas)

Jika $\mathrm{t}_{\text {hitung }}>\mathrm{t}_{\text {tabel }}$ dan $\mathrm{t}_{\text {hitung }}<-\mathrm{t}_{\text {tabel }}$ maka Ho ditolak dan Hi tidak ditolak

(Berarti variabel bebas secara individual berpengaruh terhadap variabel dependen)

\section{Variabel LDAU}

Dari hasil estimasi diperoleh nilai t-statistik untuk variabel LDAU yaitu sebesar 19,091. Apabila dibandingkan dengan nilai t tabel, maka dapat dilihat bahwa nilai t-hitung variabel ini lebih besar dari batas kanan t-tabelnya dengan ketentuan $\quad \mathrm{df}_{(\alpha, \mathrm{n}-\mathrm{k})}=\mathrm{df}_{(0,025 ; 10)}=2.228$, maka dapat disimpulkan bahwa variabel LDAU berpengaruh terhadap variabel LBD.

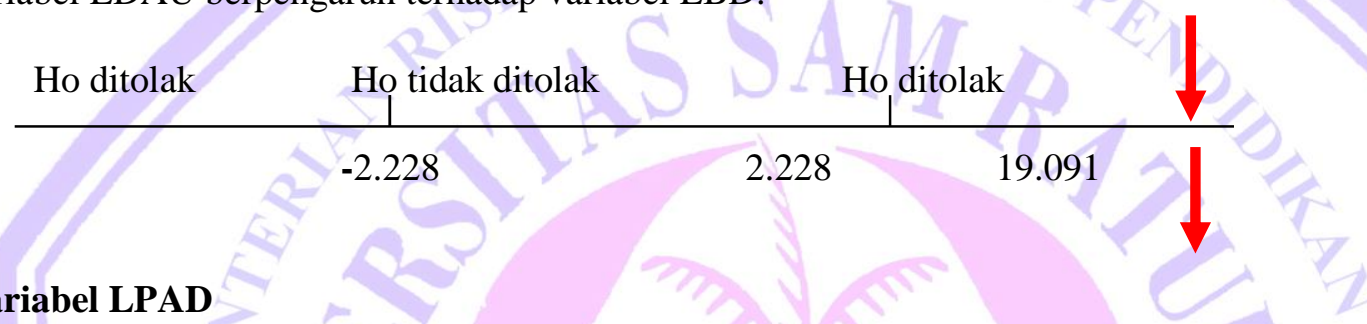

\section{Variabel LPAD}

Dari hasil estimasi diperoleh nilai t-statistik untuk variabel LPAD sebesar 6,584. Apabila dibandingkan dengan nilai $\mathrm{t}$ tabel, maka dapat dilihat bahwa nilai t-hitung variabel ini lebih besar dari batas kanan t-tabelnya dengan ketentuan $\mathrm{df}_{(\alpha, \mathrm{n}-\mathrm{k})}=\mathrm{df}_{(0,025 ; 10)}=2.228$, maka dapat disimpulkan bahwa variabel LPAD berpengaruhi terhadap variabel LBD.

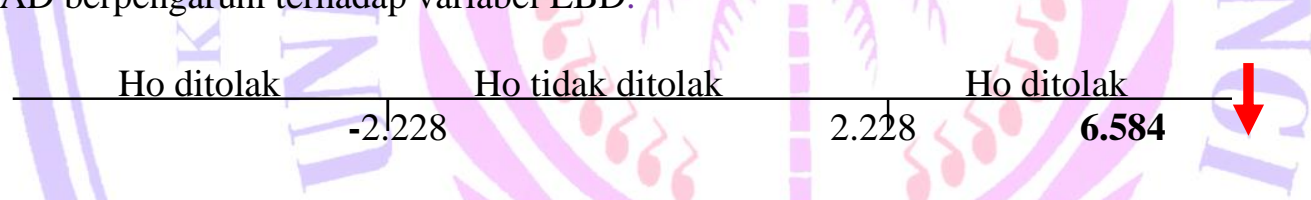

\section{Koefisien Determinasi}

Dari hasil regresi, diperoleh hasil bahwa nilai $\mathrm{R}^{2}$ sebagai koefisien determinasi untuk hubungan LPAD dengan LBD sebesar 0,81. Hal ini menunjukkan bahwa variabel bebas pada persamaan tersebut, yaitu LPAD menerangkan $\pm 81 \%$ variasi LBD, sedangkan sisanya sebesar $\pm 19 \%$ dijelaskan oleh faktor-faktor lain yang tidak dimasukkan dalam persamaan. Koefisien determinasi pada hubungan antara LDAU dengan LBD sebesar 0,97. Hal ini menunjukkan bahwa variabel bebas pada persamaan tersebut, yaitu LDAU menerangkan $\pm 97 \%$ variasi LBD, sedangkan sisanya sebesar $\pm 3 \%$ dijelaskan oleh faktor-faktor lain yang tidak dimasukkan dalam persamaan.

\section{Analisis Regresi Berganda: Pengaruh DAU dan PAD terhadap BD}

Analisis hasil regresi membahas tentang hubungan antara variabel independen terhadap variabel dependen. Dalam penelitian ini menjadikan pertumbuhan belanja daerah (LBD) sebagai variabel tidak bebas, variabel pertumbuhan dana alokasi umum (LDAU) dan pendapatan asli daerah (PAD) sebagai variabel bebas. Estimasi dilakukan dengan metode Ordinary Least Square (OLS). Hasil estimasinya dapat dilihat pada tabel 3 . 
Tabel 3 Pengaruh DAU \& PAD Terhadap BD

\begin{tabular}{|ccccc|}
\hline LBD & $=$ & $-3.15048+0.06607$ LPAD + & 1.073271 LDAU \\
Std. Error & 1.346309 & 0.053317 & 0.091107 \\
$t$-Statistic & -2.34009 & 1.239177 & 11.78037 \\
$R^{2}$ & $=0.975786$ & Adjusted & $R^{2}=0.970405$ & \\
$D-W$ stat & $=1.388336$ & F stat & $=181.3414$ & \\
\hline
\end{tabular}

Sumber: Output Eviews

\section{Pengujian Statistik \\ Uji t-stat}

Dari hasil perhitungan yang telah diperoleh dilakukan pengujian $t$ statistik untuk mengetahui bagaimana pengaruh tiap variabel bebas secara parsial terhadap LBD di Kota Bitung.

Dengan menguji dua arah dalam tingkat signifikansi (Confidence Level atau $C L$ ) dan derajat kebebasan $($ degree of freedom $)=(\alpha / 2, n-k)$, dimana $\alpha$ menunjukkan tingkat kepercayaan analisis $=5 \%$ atau $0,05, \mathrm{n}$ menunjukkan jumlah observasi $=12$, dan $\mathrm{k}$ menunjukkan jumlah parameter termasuk konstanta $=3$, hasil pengujian akan menghasilkan kesimpulan:

Bila $-\mathrm{t}_{\text {tabel }}<\mathrm{t}_{\text {hitung }}<\mathrm{t}_{\text {tabel }}$ maka Ho tidak ditolak dan menolak Hi

Berarti variabel bebas secara individual tidak berpengaruh terhadap variabel tak bebas

Jika $\mathrm{t}_{\text {hitung }}>\mathrm{t}_{\text {tabel }}$ dan $\mathrm{t}_{\text {hitung }}<-\mathrm{t}_{\text {tabel }}$ maka Ho ditolak dan Hi tidak ditolak

Berarti variabel bebas secara individual berpengaruh terhadap variabel tak bebas

\section{Variabel LPAD}

Dari hasil estimasi diperoleh nilai t-statistik untuk variabel LPAD sebesar 1,239. Apabila dibandingkan dengan nilai $t$ tabel, maka dapat dilihat bahwa nilai t-hitung variabel ini lebih kecil dari batas kanan t-tabelnya dengan ketentuan $\mathrm{df}_{(\alpha / 2, \mathrm{n}-\mathrm{k})}=\mathrm{df}_{(0,025 ; 10)}=2.228$, maka dapat disimpulkan bahwa variabel LPAD tidak mempengaruhi variabel LBD.

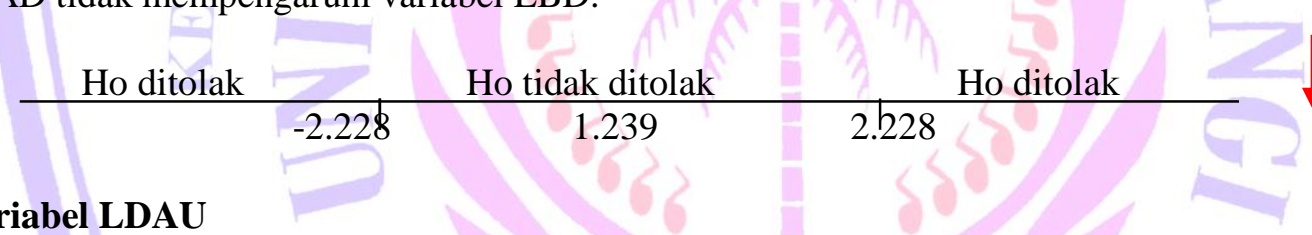

\section{Variabel LDAU}

Dari hasil estimasi diperoleh nilai $t$-statistik untuk variabel LDAU sebesar 11.780. Apabila dibandingkan dengan nilai t tabel, maka dapat dilihat bahwa nilai t-hitung variabel ini lebih kecil dari batas kanan ttabelnya dengan ketentuan $\mathrm{df}_{(\alpha, \mathrm{n}-\mathrm{k})}=\mathrm{df}_{(0,025 ; 10)}=2.228$, maka dapat disimpulkan bahwa variabel LDAU signifikan secara statistik mempengaruhi.

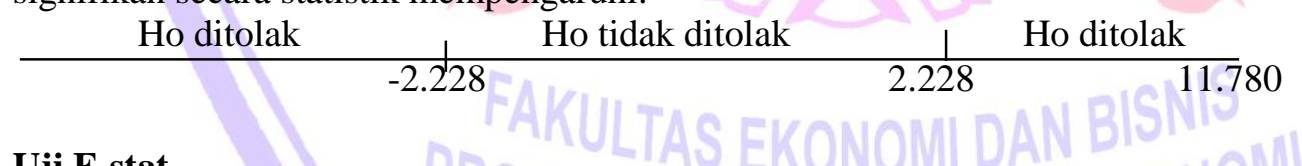

\section{Uji F-stat}

Uji $\mathrm{F}$ digunakan untuk mengetahui apakah variabel-variabel independen dalam persamaan regresi tersebut mempengaruhi variabel dependen secara bersamaan dengan tingkat signifikansi tertentu.

Berdasarkan hasil perhitungan yang telah dilakukan, diperoleh nilai $\mathrm{F}$ hitung sebesar 181.314. Jika nilai ini dibandingkan dengan nilai $\mathrm{F} \operatorname{tabel}_{(0.05, \mathrm{k}-1=2, \mathrm{n}-\mathrm{k}=10)}$ adalah 4,10 , maka diperoleh hasil bahwa nilai $\mathrm{F}$ hitung $>$ F tabel, berarti Ho ditolak, hal ini berarti bahwa pada persamaan regresi diatas variabel bebas (LPAD dan LDAU) secara bersama-sama (simultan) menjelaskan variasi pergerakan variabel tak bebas (LBD).

\section{Koefisien Determinasi}

Dari hasil regresi yang dilakukan terhadap model pendapatan petani padi, diperoleh hasil bahwa nilai $\mathrm{R}^{2}$ sebagai koefisien determinasi adalah 0.975 . Hal ini menunjukkan bahwa variabel-variabel bebas pada persamaan tersebut, yaitu LPAD dan LDAU secara bersama-sama menerangkan $\pm 97 \%$ variasi LBD, sedangkan sisanya sebesar $\pm 3 \%$ dijelaskan oleh faktor-faktor lain. 


\section{Uji Asumsi Klasik}

Uji Normalitas

Hasil Uji Normalitas dengan menggunakan Jarque-Berra Test (JB Test) ditunjukkan pada gambar 4.11. Hasil menunjukkan bahwa Model Belanja Daerah dilihat dari Jarque-Bera normality statistic adalah sebesar 0.952464 lebih kecil dari nilai 2. Selain itu ditunjukkan juga oleh angka Probability sebesar 0.621119\% yang lebih besar dari $0.05 \%$. Hal ini membuktikan bahwa data telah berdistribusi normal (Pratomo, 2007).

\section{Heteroskedastisitas}

Hasil Uji Heteroskedastisitas dengan menggunakan Uji White menunjukkan bahwa Model Belanja Daerah tidak terdapat heteroskedastisitas. Hal tersebut dibuktikan dari hasil Uji White, dimana angka probabilita dari Obs*R-Squared pada hasil estimasi adalah lebih besar dari $0.05 \%$ yaitu sebesar $0.642545 \%$. Tabel 4 . Menunjukkan hasil pengujian dengan Uji White (Pratomo, 2007).

\section{Tabel 4 Hasil Uji White}

\begin{tabular}{|l|l|l|l|}
\hline F-statistic & 0.469356 & Prob. F(5,5) & 0.787996 \\
\hline Obs*R-squared & 3.373918 & Prob-square(5). Chi & 0.642545 \\
\hline \multicolumn{2}{|c|}{ Sumber : Output Eviews }
\end{tabular}

\section{Multikolinieritas}

Yang dimaksud dengan multikolinearitas adalah adanya hubungan linier antarvariabel bebas yang terdapat dalam suatu model (Widarjono, 2006), Ciri-ciri adanya multikolinearitas dapat ditunjukkan oleh beberapa faktor, namun yang paling mendukung penjelasan adanya gejala multikolinearitas dalam model adalah jika dalam hasil regresi diperoleh nilai $\mathrm{R}^{2}$ yang tinggi (mendekati 1), tetapi tidak satupun atau sangat sedikit koefisien yang ditaksir signifikan secara statistik (melalui uji $\mathrm{F}$ dan uji $\mathrm{t}$ ). Untuk mengetahui ada tidaknya multikolinearitas dapat digunakan melalui cara uji korelasi yaitu Coefficient Correlation Matrix (Pratomo, 2007). Hal ini dapat dilihat pada tabel 5. Tabel 5 menunjukkan bahwa variabel PAD dan DAU nilai koefisiennya yang lebih besar 0.80 . Hal ini berarti kemungkinan adanya multikolinearitas (Gujarati, 2003).

Tabel 5 Coefficient Correlation Matrix

\begin{tabular}{|c|c|c|}
\hline D & LPAD & LDAU \\
\hline LPAD & 1 & 0.890723 \\
\hline LDAU & 0.890723 & 12 \\
\hline
\end{tabular}

\section{Otokorelasi}

Penaksiran model regresi linier normal klasik mengandung asumsi bahwa tidak terdapat korelasi serial diantara disturbance term atau autokorelasi, untuk menguji apakah dalam model tersebut terdapat autokorelasi dapat diuji dengan Uji Lagrange Multiplier (LM Test). Dari tabel 4.7 diperoleh hasil LM Test menunjukkan bahwa nilai probability 0.395310 lebih tinggi dari 0,05 . Hal ini berarti tidak terdapat otokorelasi dari hasil estimasi tersebut (Pratomo, 2007).

Tabel 6 Breusch-Godfrey

\begin{tabular}{|l|l|l|l|}
\hline $\begin{array}{l}\text { Serial Correlation LM Test } \\
\text { F-statistic }\end{array}$ & 0.640447 & Prob. F(2,7) & 0.555358 \\
\hline Obs*R-squared & 1.856168 & Prob. Chi-Square(2) & 0.395310 \\
\hline
\end{tabular}

Sumber : Output Eviews

\section{Interpretasi Ekonomi Hasil Regresi Sederhana dan Regresi Berganda Hubungan LPAD dan LDAU dengan LBD}

Dari hasil regresi dapat diperoleh informasi mengenai pengaruh variabel-variabel bebas dalam persamaan tersebut terhadap variabel tak bebasnya. Dalam hal ini variabel bebas adalah pertumbuhan DAU dan pertumbuhan PAD dan sebagai variabel tidak bebas yaitu pertumbuhan belanja daerah (LBD). Nilai 
koefisien regresi pada masing-masing variabel bebas menunjukkan berapa besar pengaruh dari variabel bebas terhadap perubahan variabel tak bebasnya, ceteris paribus. Tanda positif yang menyertai koefisien regresi mengandung arti bahwa arah perubahan variabel bebas dan perubahan tak bebasnya berbanding lurus, sedangkan tanda negatif yang menyertai koefisien regresi mengandung arti bahwa arah perubahan variabel bebas dan variabel tak bebasnya berlawanan.

Interpretasi Ekonomi Hasil Regresi Sederhana: Pengaruh LPAD Terhadap LBD

Hasil regresi hubungan LPAD terhadap LBD di Kota Bitung ditunjukan pada persamaan 7.
LBD =
13.74 + 0.54 LPAD

\section{Koefisien $\alpha_{0}$ (Intercept / Konstanta)}

Koefisien $\alpha_{0}$ memberikan (menggambarkan) pengaruh efek rata-rata semua faktor yang tidak dimasukkan persamaan. Secara mekanis ini adalah nilai pertumbuhan BD saat nilai variabel bebas disamakan dengan nol. Ini menunjukkan bahwa tanpa adanya perningkatan $\mathrm{PAD}$, maka $\mathrm{BD}$ untuk satu periode mendatang akan mengalami perubahan yang positif atau akan meningkat sebesar 13,74 persen.

\section{Koefisien $\alpha_{1}$ (variabel LPAD)}

Nilai koefisien untuk Variabel LPAD sebesar 0,54 dan signifikan, menunjukkan bahwa pertumbuhan belanja daerah di Kota Bitung memiliki hubungan yang positif dengan berubahnya PAD. Dengan perkataan lain, selama periode yang diteliti, dengan menjaga agar variabel-variabel lain tetap, $1 \%$ peningkatan dalam PAD akan meningkatan rata-rata sekitar $0,54 \%$ dalam pertumbuhan belanja daerah Kota Bitung.

Hasil ini sesuai dengan hasil penelitian yang dilakukan oleh Aziz et al, (2000) dan Doi, (1998). Hipotesis yang menyatakan bahwa pendapatan daerah (terutama pajak) akan mempengaruhi belanja pemerintah daerah dikenal dengan nama tax spend hypothesis, dalam hal ini pengeluaran pemerintah daerah akan disesuaikan dengan perubahan dalam penerimaan pemerintah daerah atau perubahan pendapatan terjadi sebelum perubahan pengeluaran (Prakosa, 2004).

Interpretasi Ekonomi Hasil Regresi Sederhana: Pengaruh LPAD Terhadap LBD Hasil regresi hubungan LDAU terhadap LBD di Kota Bitung ditunjukan pada persamaan 8

$$
\mathrm{LBD}=\quad-6,99+1,28 \mathrm{LDAU} \text {. }
$$

\section{Koefisien $\alpha_{0}$ (Intercept / Konstanta)}

Koefisien $\alpha_{0}$ memberikan (menggambarkan) pengaruh efek rata-rata semua faktor yang tidak dimasukkan persamaan. Secara mekanis ini adalah nilai pertumbuhan BD saat nilai variabel bebas disamakan dengan nol. Ini menunjukkan bahwa tanpa adanya perningkatan DAU, maka BD untuk satu periode mendatang akan mengalami perubahan yang negatif atau akan menurun sebesar 6,99 persen.

\section{Koefisien $\alpha_{1}$ (variabel LDAU)}

Nilai koefisien untuk Variabel LDAU sebesar 1,28 dan signifikan, menunjukkan bahwa pertumbuhan belanja daerah di Kota Bitung memiliki hubungan yang positif dengan berubahnya DAU. Dengan perkataan lain, selama periode yang diteliti, dengan menjaga agar variabel-variabel lain tetap, $1 \%$ peningkatan dalam DAU akan meningktan rata-rata sekitar 1,28\% dalam pertumbuhan belanja daerah Kota Bitung.

Hasil ini sesuai dengan hasil penelitian yang dilakukan oleh Legrensi \& Milas (2001) menggunakan sampel municipalities di Italia, menemukan bukti empiris bahwa dalam jangka panjang transfer berpengaruh terhadap belanja daerah. Secara spesifik mereka menegaskan bahwa variable-variabel kebijakan pemerintah daerah dalam jangka pendek disesuaikan (adjusted) dengan transfer yang diterima.

\section{Interpretasi Ekonomi Hasil Regresi Berganda: Pengaruh LPAD dan LDAU Terhadap LBD}

Dari hasil regresi berganda dapat diperoleh informasi mengenai pengaruh variabel-variabel bebas dalam persamaan tersebut terhadap variabel tak bebasnya. Dalam hal ini variabel tak bebas adalah LBD dan sebagai variabel bebas yaitu LPAD dan LDAU. Nilai koefisien regresi pada masing-masing variabel bebas menunjukkan berapa besar pengaruh dari variabel bebas terhadap perubahan variabel tak bebasnya, ceteris 
paribus. Tanda positif yang menyertai koefisien regresi mengandung arti bahwa arah perubahan variabel bebas dan perubahan tak bebasnya berbanding lurus, sedangkan tanda negatif yang menyertai koefisien regresi mengandung arti bahwa arah perubahan variabel bebas dan variabel tak bebasnya berlawanan.

Hasil regresi hubungan LPAD dan LDAU terhadap LBD ditunjukan pada persamaan 9.

$$
\text { LBD }=-3.15+0.07 \text { LPAD + 1.07 LDAU . }
$$

\section{Koefisien $\alpha_{0}$ (Intercept / Konstanta)}

Koefisien $\alpha_{0}$ dalam persamaan pendapatan petani padi tersebut memberikan (menggambarkan) pengaruh efek rata-rata semua faktor yang tidak dimasukkan ke dalam persamaan 4.3. Secara mekanis ini adalah nilai pendapatan saat nilai ketiga variabel bebas disamakan dengan nol. Ini menunjukkan bahwa tanpa adanya perubahan pada LPAD dan LDAU, maka perkembangan LBD untuk satu periode mendatang akan mengalami perubahan yang negatif atau menurun sebesar 3,15\%.

\section{Koefisien $\alpha_{1}$ (variabel LPAD)}

Nilai koefisien sebesar 0.07 akan tetapi tidak signifikan. Hal ini menunjukkan bahwa perkembangan belanja daerah Kota Bitung memiliki hubungan yang positif dengan berubahnya PAD. Dengan perkataan lain, selama periode yang diteliti, dengan menjaga agar variabel-variabel lain tetap, 1 persen peningkatan dalam PAD akan mengakibatkan peningkatan rata-rata sekitar 0.07 persen dalam belanja daerah.

\section{Koefisien $\alpha_{2}$ (variabel LDAU)}

Nilai koefisien sebesar 1,07 dan signifikan menunjukkan bahwa perkembangan belanja daerah memiliki hubungan yang positif dengan perubahan dana alokasi umum. Dengan perkataan lain, selama periode penelitian, dengan menjaga agar variabel-variabel lain tetap, 1 persen peningkatan DAU akan mengakibatkan peningkatan rata-rata sekitar 1,07 persen dalam belanja daerah Kota Bitung.

Hasil regresi menunjukkan bahwa dari kedua variabel bebas yaitu LDAU dan LPAD, variabel LDAU memiliki pengaruh lebih daripada variabel LPAD. Di samping itu walaupun variabel LPAD mempunyai hubungan positif dengan LBD akan tetapi tidak berpengaruh terhadap perubahan LBD. Hasil ini sesuai penelitian yang dilakukan oleh Prakosa (2004). Hasil penelitian menunjukkan bahwa secara empiris ditemukan bahwa besarnya belanja daerah dipengaruhi oleh jumlah DAU yang diterima dari pemerintah pusat. Dalam model prediksi belanja daerah, daya prediksi DAU terhadap belanja daerah lebih tinggi dibanding dengan daya prediksi PAD.

\section{Pengujian Terhadap Flypaper Effect}

Flypaper effect merupakan suatu kondisi keuangan pemerintah daerah yang membelanjakan lebih banyak atau lebih boros dengan menggunakan dana transfer dari pemerintah pusat (DAU) dibandingkan menggunakan dana sendiri (PAD). Untuk menentukan apakah terjadi flypaper effect, maka efek DAU terhadap $\mathrm{BD}$ dibandingkan dengan efek PAD terhadap $\mathrm{BD}$, baik untuk model regresi sederhana maupun untuk regresi berganda dengan melihat koefisien regresi, nilai t-statistic, F-statistic, standard error, $\mathrm{R}^{2}$, dan Adjusted $\mathrm{R}^{2}$ masing-masing variabel (regresi) dibandingkan antara DAU dan PAD. Apabila efek yang ditimbulkan oleh perubahan DAU terhadap BD lebih besar daripada efek yang ditimbulkan PAD terhadap BD maka dapat disimpulkan terjadi flypaper effect, (Halim dan Abdulah, 2004).

Perbandingan hasil regresi sederhana dengan dapat dilihat dalam tabel Hasil regresi sederhana yang ditunjukkan dapat dilihat bahwa koefisien estimasi, nilai t-statistic, $\mathrm{R}^{2}$, menunjukkan LDAU lebih besar daripada LPAD, hal ini berarti bahwa pengaruh LDAU terhadap LBD lebih besar daripada pengaruh LPAD terhadap LBD. Hal ini berarti bahwa keberadaan Flypaper Effect terbukti, (Halim dan Abdulah, 2004).

Ada tidaknya keberadaan Flypaper Effect dalam pengelolaan keuangan daerah Kota Bitung dapat juga dilihat dari hasil regresi berganda hubungan LPAD dan LDAU terhadap LBD yang ditunjukkan pada tabel 4.4. Dari hasil regresi berganda dapat dilihat pengaruh LDAU dan LPAD secara serempak terhadap LBD.

Koefisien estimasi LPAD sebesar 0,07 tidak signifikan, sedangkan koefisien LDAU sebesar 1,07 signifikan. Nilai t-statistik untuk LPAD sebesar 1,24 dan untuk LDAU sebesar 11,78, ini menunjukkan bahwa nila t-statistik LDAU lebih besar dari nilai t-statistik LPAD. Hal ini berarti LDAU lebih kuat untuk 
menolak hipotesis nol $\left(\mathrm{H}_{0}\right)$ dan menerima hipotesis alternatif $\left(\mathrm{H}_{1}\right)$ dibandingkan dengan LPAD, (Suharyadi, 2009). Hasil regresi berganda secara keseluruhan menunjukkan bahwa pengaruh LDAU lebih besar/kuat dibandingkan dengan pengaruh LPAD terhadap LBD, hal ini membuktikan adanya flypaper effect, (Halim dan Abdulah, 2004).

Dengan demikian dari hasil regresi sederhana dan regresi berganda menunjukkan bahwa peningkatan pendapatan asli daerah (PAD) dan dana alokasi umum (DAU) berpengaruh positif terhadap peningkatan belanja daerah (BD) dan dalam pengelolaan keuangan daerah Kota Bitung Tahun Anggaran 2004-2015 membuktikan terjadinya Flypaper Effect. Hal ini berarti Pemerintah Kota Bitung dalam memprediksi Belanja Daerahnya (BD) lebih mengutamakan Dana Transfer (DAU) yang bersumber dari pemerintah pusat, bukan berdasarkan kemampuan keuangannya sendiri yang diproksi dari penerimaan Pendapatan Asli Daerah (PAD).

\section{KESIMPULAN DAN SARAN}

\section{Kesimpulan}

1. Peningkatan pendapatan asli daerah (PAD) berpengaruh positif terhadap peningkatan belanja daerah (BD), yang artinya peningkatan PAD akan meningkatkan belanja daerah Kota Bitung.

2. Dana Alokasi Umum (DAU) yang merupakan dana transfer tidak bersyarat yang bersumber dari pemerintah pusat berpengaruh positif terhadap peningkatan belanja daerah, yang artinya peningkatan DAU akan meningkatkan belanja daerah Kota Bitung.

3. Pengelolaan keuangan daerah Kota Bitung tahun anggaran 2004-2015 terjadi Flypaper Effect. Hal ini berarti Pemerintah Kota Bitung dalam memprediksi Belanja Daerahnya (BD) lebih mengutamakan Dana Transfer (DAU) yang bersumber dari pemerintah pusat, bukan berdasarkan kemampuan keuangannya sendiri yang diproksi dari penerimaan Pendapatan Asli Daerah (PAD).

\section{Saran}

Mengingat PAD sangat berpengaruh terhadap belanja daerah di Kota Bitung, maka peningkatan efektivitas dan efisiensi dalam perolehan sumber-sumber PAD harus lebih diintensifkan, sehingga Pemerintah Daerah tidak lagi bergantung pada Dana Alokasi Umum (DAU) dalam pembiayaan daerahnya melainkan memaksimal penerimaan PAD sehingga daerah dapat mandiri dalam pelaksanaan otonomi daerah

- Belanja Daerah dalam proporsi penggunaannya haruslah lebih besar dialokasikan ke Belanja Modal sehingga dapat mempercepat pembangunan di Kota Bitung.

- Penelitian ini masih jauh dari sempurna, untuk itu disaran untuk penelitian selanjutnya sebaiknya periode waktu/tahun penelitian dan sampel daerah yang digunakan ditambah sehingga menghasilkan informasi yang lebih mendukung. Disamping itu variabel pengeluaran pemerintah daerah (BD) dibuat menjadi beberapa variabel sesuai dengan rincian atau item pengeluaran pemerintah atau belanja pemerintah daerah sehingga nantinya diharapkan kesimpulan yang diperoleh lebih sempurna.

\section{DAFTAR PUSTAKA}

Afrizawati. 2012. Analisis Flypaper Effect Pada Belanja Daerah Kabupaten/Kota Di Sumatera Selatan. Jurnal Ekonomi Dan Informasi Akuntansi Volume 2 No. 1.

Aziz, Mariam Abdul, Muzafar Shah Habubullah, W.N.W. Azmani-Saini, \& M. Azali. 2000. Thecausal relationship between tax revenues and Government spending in Malaysia. University Putra Malaysia, Working Paper.

Bradford, D. \& W. Oates, 1971, The analysis of revenue sharing in a new approach to collective fiscal decision. Quarterly journal of Economics 85(3 hang, Tsangyao \& Yuan Hong Ho. 2002. Tax or spend, what cause what: Taiwan's experience. International Journal of Businees and Economics 1 (2) : $157-165$.

Doi, Takero, 1998, Is Japanese Local Finance really centralized? From viewpoint of the revenueexpenditurenexus. University of Tokyo, Working Paper 
Dumairy, 1997, Perekonomian Indonesia, Erlangga, Jakarta

Emelia, 2006. Mengukur Tingkat Kemandirian Keuangan Daerah dalam emdorong pelaksanaan Otonomi Daerah Periode 2000-2004 di Kabupaten Lampung Timur. Skripsi tidak dipublikasikan, Fakultas Ekonomi Universitas Islam Indonesia Yogyakarta.

Gamkhar, Shama \&Wallace Oates. 1996. Asymetries in response to increase and decrease in intergovernmental grants: some empirical findings. National Tax Journal 49 (4):501-512.

Gujarati, Damodar. 2003. Basic Econometrics, Fourth edition., MCgraw Hill

Halim, Abdul \& Sukriy, Abdullah., 2004. Pengaruh Dana Alokasi Umum (DAU) dan Pendapatan Asli Daerah (PAD) terhadap Belanja Pemerintah Daerah Studi kasus Kabupaten/Kota di Jawa dan Bali. Yogyakarta ; Jurnal Ekonomi STEI No.2/Th.XIII/25/April-Juni 2004 :90-109.

Hamdani Surya, dkk. 2014. Pengaruh Alokasi DAU Dan Pendapatan Asli Daerah Terhadap Belanja Daerah Pada Kabupaten/Kota Di Provinsi Kalimantan Timur. FE Universitas Mulawarman.

Handayani Atiah. 2009. Analisis Pengaruh Transfer Pemerintah Pusat terhadap Pengeluaran Daerah dan Upaya Pajak (Tax Effort) Daerah (Studi Kasus Kabupaten/Kota di Jawa Tengah). Skripsi. Ilmu Ekonomi dan studi Pembangunan, Universitas Doponegoro Semarang.

Hines James R., Jr., and Richard H. Thaler, 1995, Anomalies: The Flypaper Effect, Journal of Economic Perpective 9 (4) : 217-226.

Jaya WK, 2002, Analisa Keuangan Daerah:Pendekatan Makro, Model Program PMSS ES, Kerjasama ditjen PUOD Depdagri dengan Pusat Penelitian dan Pengkajian Ekonomi dan Bisnis UGM

Jhingan, M.L., 2005. Ekonomi Pembangunan dan Perencanaan. Edisi Bahasa Indonesia. CV Rajawali. Jakarta.

Joulfaian, D. \& R. Mookejee, 1990, The interporal relationship between state and local government revenues and expeditures : evidence from OECD countries. PublikFinance 45:109-117

Kawedar, Warsito, Abdul Rohman, dan Sri Handayani. 2007. Akuntasi Sektor Publik: Pendekatan Penganggaran Daerah dan Akuntasi Keuangan Daerah. Penerbit UNDIP:Semarang.

Kuncoro, Mudrajad. 2004. Otonomi \& Pembangunan Daerah, Erlangga, Jakarta.

Kuncoro, Mudrajad. 1997. Ekonomi Pembangunan: Teori, Masalah dan Kebijakan. UPP AMP YKPN, Yogyakarta

Maarten Allers Wouter Vermeulen, 2014, Fiscal equalization, capitalization and the flypaper effect.

Legrenzi. Gabriella \&Costas Milas. 2001. Non-linear and asymetrics adjustment in the local revenueexpenditure models: some evidence from the Italian municipalities. University of Milan. Working Paper.

Mahmudi., 2010. Analisis Laporan Keungan Pemerintah Daerah. UPP STIM YKPN. Yogykarta

Mutiara Maimunah. 2006. Flypaper Effect pada Dana Alokasi Umum (DAU) dan Pendapatan Asli Daerah (PAD) terhadap Belanja Daerah pada Kabupaten/ Kota di Pulau Sumatera. Paper disajikan pada simposium Nasional Akuntasi IX Padang.

Mardiasmo. 2002. Otonomi dan Manajemen Keuangan Daerah. Penebit Andi: Yogyakarta.

Musgrave R.A and Musgrave P.B, 1993, Keuangan Negara Dalam Teori dan Praktek, Edisi ke lima, Penerbit Erlangga, Jakarta.

Nagathan, dan KJ Sivagnanan. 1999. Federal transfer and tax effort of states in India. Indian Economic Journal.

Nawatmi, Sri, Faktor-faktor yang mempengaruhi Jumlah bantuan Pemerintah Pusat di lima Kabupaten/Kota di Jawa Tengah, Jurnal Ekonomi dan Bisnis Volume 13 No. 2, September, 2006

Oates, Wallace.1999. an essay of fiscalfederalism. Journal of Economics Literature 37:1120-1149.

Pratiwi, Novi. 2007. Pengaruh Dana Alokasi Umum (DAU) dan Pendapatan Asli Daerah (PAD) terhadap perdiksi Belanja Daerah pada Kabupaten/Kota di Indonesia. Skripsi Sarjana (dipublikasikan). Fakultas Eknomi UII; Yogyakarta.

Prakosa, Kesit Bambang, 2004. Analisis Pengaruh Dana Alokasi Umum (DAU)dan Pendapatan Asli Daerah (PAD) terhadap prediksi belanja daerah;studi empiric di wilayah Provinsi Jawa Tengah dan DIY, JAAI Vol08 No2.

Pratomo P.A.., 2007. Pedoman Praktis Penggunaan Eviews, USU Press, Medan. 
Purnomo, Bayu, 2011 Flypaper Effect pada Pengaruh transfer tidak bersyarat dan pendapatan asli daerah (PAD) terhadap Pertumbuhan Ekonomi Daerah Kabupaten/ Kota di Kalimantan Tahun 2007-2010.

Rosen, H.S., 2002, Publik Finance, edisi keenam, MC-Graw Hill Book.co.,New York.

Rusydi Bahrul, 2010, Analisis Determinan Kinerja Keuangan Pemerintah Daerah dan Deteksi Ilusi Fiskal (Studi Kasus Provinsi di Indonesia) Tahun 2005-2008), Skripsi tidak dipublikasikan. Ilmu Ekonomi dan Studi Pembangunan, Fakultas Ekonomi Universitas Diponegoro. Semarang.

San-Seok Bae* and Richard C. Feiock, 2004, The Flypaper Effect Revisited: Intergovernmental Grants and Local Governance.

Shah, A., 1994, The Reform of Intergovernmental Fiscal Relations in Developing and Emerging Market Economies, Policy and Paper Series, No. 23, The World Bank, Washington, DC.

Suharyadi, dan Purwanto, 2009, Statistika : Untuk Ekonomi dan Keuangan Modern, Salemba Empat, Jakarta. Suparmoko., 2002. Ekonomi Publik untuk Keuangan dan Pembangunan Daerah edisi pertama, Penerbit Andi, Yogyakarta.

Suparmako, 2011. Keuangan Negara, Edisi keenam, BPFE, Yogyakarta.

Suranta, Sri dan Muhammad Syafiqurrahman, 2005. Eksistensi Pajak Daerah Melalui Pajak Parkir Sebagai Upaya Peningkatan Pendapatan Asli Daerah di Surakarta, Empirika Vol 18 No1, Juni.

Todaro M.P., 2000. Pembangunan Ekonomi di Dunia Ketiga, Jilid 2 edisi keempat, Arlangga, Jakarta.

Widarjono, Agus, 2013, Ekonometrika : Pengantar dan Aplikasinya. UPP STIM YKPN. Yogyakarta.

Widiyanto, Analisis Pengaruh Dana Alokasi Umum (DAU) dan Pendapatan Asli Daerah (PAD) terhadap belanja daerah di Kabupaten/Kota Jawa Tengah dan DIY, Skripsi Sarjana (tidak dipublikasikan). Yogyakarta; Fakultas Ekonomi UII, 2005.

Peraturan Pemerintah Republik Indonesia No 58 tahun 2005 tantang Pengelolaan Keuangan Daerah.

Republik Indonesia. 2004. Undang-Undang Republik Indonesia Nomor 32 Tahun 2004 tentan Pemerintah Daerah.

Republik Indonesia. 2004 Undang-Undang RepublikIndonesia nomor 33 tahun 2004 tantang Perimbangan Keuangan antara Pemerintah Pusat dan Pemerintah Daerah. 